\title{
Late-onset asthma: current perspectives
}

This article was published in the following Dove Press journal:

Journal of Asthma and Allergy

\section{Tsunahiko Hirano \\ Kazuto Matsunaga}

Department of Respiratory Medicine and Infectious Disease, Graduate School of Medicine, Yamaguchi University, Yamaguchi, Japan
Correspondence: Tsunahiko Hirano Department of Respiratory Medicine and Infectious Disease, Graduate School of Medicine, Yamaguchi University, I-I-I Minami-kogushi, Ube, 755-8505 Japan $\mathrm{Tel}+81836853123$

Fax +8I 836853124

Email tsuna@yamaguchi-u.ac.jp
Abstract: Because the pathophysiology of asthma has diverse characteristics, to manage the disease effectively, it is important for clinicians to distinguish among the clinical phenotypes. Among them, adult-onset asthma, that is, late-onset asthma (LOA), is increasing because of the aging of the population. The phenotype of LOA is largely divided into two types according to the presence or absence of eosinophilic inflammation, T-helper (Th)2- and non-Th2-associated LOA. Especially in Th2 LOA related to rhinosinusitis, as pulmonary function at onset is poor and asthma exacerbations occur frequently, it is important to detect this phenotype in the early phase by using a biomarker of Th2-type inflammation such as fractional exhaled nitric oxide $\left(\mathrm{FE}_{\mathrm{NO}}\right)$. As non-Th2-LOA is often resistant to corticosteroids, this phenotype often requires another treatment strategy such as macrolide, diet, or smoking cessation. We often struggle with the management of LOA patients due to a lack of evidence; therefore, the elucidation of the mechanism of LOA contributes to increased efficiency of diagnosis and treatment of LOA. Age-related immune system and structural changes are thought to be associated with the pathophysiology of LOA. In the former case, changes in inflammatory cell function such as variations in the innate immune response and acquisition of autoimmunity or upregulation of oxidative stress are thought to be involved in the mechanism. Meanwhile, the latter can also become triggers or exacerbating factors of LOA via enhancement of airway hyperresponsiveness, decline in lung function, increased air trapping, and reduction in chest wall compliance. Therefore, appropriate individualized management in LOA may be possible through precisely assessing the pathophysiology based on age-related functional changes, including the immune and structural system.

Keywords: aging, immunosenescence, rhinosinusitis, obesity, phenotype, endotype

\section{Introduction}

Many patients develop asthma during childhood; however, asthma symptoms can occur at any time in life. Several factors may make a person more likely to develop late-onset asthma (LOA). ${ }^{1-3}$ For example, women are more likely to develop asthma after the age of 20, and obesity also appears to increase the risk of developing asthma as an adult. ${ }^{4}$ Moreover, individuals who had asthma as a child may see asthma recur later in life. ${ }^{5}$ In any case, because of the worldwide population trend toward enhanced longevity, clinical concerns about LOA are developing and have been increasingly recognized by clinicians. However, the mechanisms that underlie the relationship between aging and asthma are still unclear and the condition is frequently underdiagnosed in older age groups. ${ }^{6}$ In this review, we discuss these issues with a focus on the pathophysiology and treatment of LOA. 


\section{Clinical feature}

Usually, asthma symptoms appear early in life. However, some people develop asthma symptoms for the first time in adulthood; their clinical status is called LOA, defined as: "asthma with onset of symptoms in adult life in a patient with no pre-existing, persistent respiratory symptoms," but the definition of age has not been clarified. ${ }^{7}$ It is reported that the age- and sex-adjusted incidence of newly diagnosed asthma in people older than 65 years was estimated by $0.1 \%$ per year. ${ }^{8}$

Aging itself, however, has a significant effect on the methacholine response and has an impact on airway hyperreactivity. ${ }^{9}$ Therefore, higher annual declines in $\mathrm{FEV}_{1}$ are observed in LOA, ${ }^{10-12}$ especially among elderly people ${ }^{13}$ or smokers of over 10 pack-years. ${ }^{14,15}$ Obesity-associated LOA is characterized by lack of atopy, female predominance, and it is suggested that obesity may cause LOA through changes in the structure of the lung or in the function of the immune system. ${ }^{16-26}$ The above risk factors are characterized by chronic inflammation and oxidative stress, with an increase in the mediators of innate immunity. Women are more likely to be affected by LOA than men. ${ }^{27}$ Possible explanations for gender differences in the rate of incidence of LOA may include endogenous and exogenous hormonal factors. ${ }^{28}$ In addition, LOA is associated with worse lung function and lower atopic status. ${ }^{10}$ Furthermore, among some patients with LOA, being elderly, having multi-comorbidities, polypharmacy, and poor inhaler technique, being inactive and home alone, as well as psychological status (depression, dementia, etc.) ${ }^{29,30}$ are beginning to be recognized as major issues. Actually, LOA is an independent risk factor for cardiovascular disease events. ${ }^{31}$

At least $9 \%-15 \%$ of LOA can be attributed to occupational exposures, and one of the mechanisms may be related to work-related stress. ${ }^{32}$ Mood disorders such as comorbid anxiety and depression are also associated with LOA. ${ }^{33}$

\section{Phenotype and endotype}

Some studies proposed clinical sub-phenotypes of LOA based on cluster analyses. ${ }^{34,35}$ At first, LOA was split down the middle and phenotypes were classified into Th2-LOA or non-Th2-LOA. ${ }^{36,37} \mathrm{Th} 2-\mathrm{LOA}$ is associated with sinusitis, nasal polyps, and, sometimes, aspirin-exacerbated respiratory disease (AERD), but appears to be equally common in males and females. ${ }^{38}$ This type is often severe from the onset and has been recently defined as uncontrolled asthma. ${ }^{39}$ Non-Th2LOA is associated with gender, obesity, smoking, and aging. However, because these analyses have been done using a cross-sectional study, the asthma variability has still not been fully examined. Therefore, a longitudinal-study is needed to clarify these complex phenotypes. Then, such analyses will become useful to predict the prognosis of LOA patients and to develop appropriate treatment strategies. ${ }^{40}$ Ilmarinen et al identified five sub-phenotypes of LOA by using long-term follow-up (12-year) data. ${ }^{40}$ This study suggested that identifying clusters with different disease prognoses is important for clinicians to determine the most effective treatment. In addition, fluctuations in lung function are a characteristic of asthma and represent a marker of brittle asthma. ${ }^{41,42}$ In this regard, detrended fluctuation analysis (DFA) has shown that intrinsic fluctuations in pulmonary function over time show a complex fractal-type behavior. ${ }^{43}$ Kaminsky et al reported that identifying patients with similar fluctuation patterns and disease stability by using DFA could be helpful for personalized treatment. ${ }^{44}$ Some patients with Th2-LOA have been reported to exhibit a distinct profile such as chronic rhinosinusitis (CRS), air trapping, and male sex..$^{45}$ Air trapping is associated with high computed tomography sinus scores, and this phenotype is frequently associated with severe exacerbations, as mentioned earlier. ${ }^{46}$ It is suggested that inflammation of the distal airways and that of paranasal sinuses are important predisposing factors for the development of exacerbations. ${ }^{46}$ In such cases, systemic inflammation-targeted management, such as with monoclonal antibodies against anti-IL-5, might be an ideal treatment to prevent future exacerbations and lung function decline ${ }^{47}$ In this manner, by using biological markers in cluster analyses, we are able to explore disease pathogenesis by analyzing endotypes based on molecular characteristics and obtain novel guidelines for treatment of severe asthma. Furthermore, as we discuss later, it is assumed that age-related changes in immune function have an impact on the airway inflammation of LOA. This change exists in both innate and adaptive immunity cells. Especially, type 2 innate lymphoid cells (ILC2) are intimately related to LOA nasal polyps of patients with chronic nasal sinusitis. ${ }^{48}$ Moreover, this endotype is related to interleukin (IL) $-4,{ }^{49}$ IL-5, and IL-13. ${ }^{50}$

\section{Pathophysiology}

\section{Immune system}

An increase in fractional exhaled nitric oxide $\left(\mathrm{FE}_{\mathrm{NO}}\right)$, which can provide noninvasive assessment of airway inflammation, was found to be associated with advancing age. ${ }^{51}$ The increase of the values may reflect the altered distribution of inflammatory cells or altered activity of inflammatory cells in the airway. Such altered activity may account for differences in clinical phenotypes between younger and older asthma subjects. ${ }^{52}$ Th2-LOA with sinusitis is reported to be associated with ILC2..$^{48,53,54}$ One of the reasons could be that these cells represent a key factor in the mucoid innate immune 
response that boosts allergic inflammation. ${ }^{55}$ Furthermore, these cells can be activated in an allergen-independent manner by IL-25, IL-33, and thymic stromal lymphopoietin, all of which are released from bronchial epithelial cells upon stimulation with air pollutants. ${ }^{56}$ Actually, it is reported that they have a greater effect on LOA than on early-onset asthma (EOA). ${ }^{57}$ Staphylococcus aureus enterotoxin (SE) sensitization is known to be an independent risk factor in asthma, ${ }^{58}$ and it is reported that SE-immunoglobulin (Ig) E sensitization with LOA in the elderly is associated with particularly severe eosinophilic asthma with CRS. ${ }^{58-63}$ Thus, it is suggested that SE-IgE sensitization could represent a clue to the pathogenesis of severe late-onset eosinophilic asthma in the elderly. ${ }^{58,64,65}$ Matsumoto et al reported that, in women with asthma, the cysteinyl leukotriene receptor 1 gene (CysLTR1) variant might be associated with sensitization to SE and age at asthma onset. ${ }^{66}$

Age-related declines in immune function, known as immunosenescence, also play a key role in the development of LOA. The immunosenescence process is boosted by oxidative stress through the increased rate of telomere shortening as a consequence of DNA damage. The coexistence of immunosenescence and viral infection promotes persistent inflammation. ${ }^{67}$ The mechanism is suggested to represent diminished B-cell function. ${ }^{68}$ In this condition, antigen persistence is enhanced, especially in the elderly, and pulmonary age-related inflammation is increased via cytokine or toll-like receptor without infection. ${ }^{69}$ In addition, autoimmunity may increase the affinity of $\mathrm{T}$ cells to self-antigens or latent viruses, thereby promoting an autoimmune process. ${ }^{70}$ In general, with age, naïve T lymphocytes in the thymic compartment as well as in the periphery are thought to decrease through thymic atrophy or loss of bone marrow function, including telomere shortening and impaired enzymes. ${ }^{71}$ By contrast, with age, the numbers of memory T lymphocyte are reported to increase. ${ }^{72,73}$ These phenomena diminish the efficiency of T-cell activation. ${ }^{72}$ However, when autoantibodies are increased in elderly individuals because of increased tissue damage and apoptosis, thymic T-regulatory cells (Tregs) become enhanced to regulate this autoimmunity. ${ }^{74} \mathrm{As}$ a result, CD4+ and CD8+ T-cell responses are reduced, and susceptibility to infection increases. Recurrent infection stimulates proinflammatory cytokines, and this leads to activation of Tregs. Consequentially, the production of Th17 is enhanced, leading to persistent chronic inflammation. With increased age, total serum $\operatorname{IgE}$ is known to decrease because of impaired B-cell-mediated antibody production and specificity. ${ }^{75}$ However, it is reported that the rate of allergen sensitization in older asthmatics is higher than that of age-matched controls. ${ }^{76}$ The difference in
B-cell activation which has caused such a status may play a potential role in autoimmunity. The risk of EOA and LOA is differently influenced by the interaction between childhood farming exposure and genetic variations. ${ }^{77}$ A genetic variation, such as on chromosome $17 \mathrm{q} 21$, or the $\mathrm{C}-\mathrm{C}$ chemokine regulated on activation, and normal T-cell expressed and secreted (RANTES) could play a part in the LOA. ${ }^{78,79}$ Age differences in the leukotriene (LT) and wingless/integrase (Wnt) pathways during airway inflammation underlie the differential development of airway remodeling. ${ }^{80}$ Thirty-eight percent of asthmatics are reported to have paucigranulocytic type disease. ${ }^{81}$ The mechanism is speculated to be derived from abnormalities or dysfunction of structural cells, such as airway smooth muscles and nerve. Therefore, increased bronchomotor tone from muscarinic and adrenergic pathways can cause symptoms, and a long-acting muscarinic antagonist might be effective therapy. ${ }^{82}$ Bronchial thermoplasty (BT) is an endoscopic procedure that targets primarily airway remodeling and improves quality of life or exacerbation with asthmatics although pulmonary function is not improved. ${ }^{83-85}$ One of the mechanisms underlying the clinical improvement is related to alterations in different bronchial structures, such as airway smooth muscles and neuroendocrine cells, without any impact on eosinophilic inflammation. ${ }^{86}$ Therefore, BT may be an option for paucigranulocytic type of severe LOA. Furthermore, murine mesenchymal stromal cells from the bone marrow are reported to have an impact on pulmonary inflammation; bronchiolitis obliterans syndrome (BOS) following organ transplantation, stem/progenitor hematopoietic stem cell transplantation ( $\mathrm{s} / \mathrm{p}$ HSCT), and immune dysregulation can contribute to the pathogenesis of LOA. ${ }^{87,88}$

\section{Pulmonary structure and function}

Additional data suggest that advanced age, irrespective of any concomitant pulmonary disease, is associated with increased bronchial hyperresponsiveness. ${ }^{9,89}$ In a study of 148 subjects, ranging from age 5 to 76 years, age had an independent association with bronchial hyperresponsiveness as measured by a methacholine challenge. ${ }^{9}$ In another study, bronchial hyperresponsiveness to histamine challenge was associated with increased eosinophil count and allergic sensitization; however, older age maintained an independent association with bronchial hyperresponsiveness, which was more prominent in subjects with respiratory symptoms. ${ }^{42}$ In addition to age, it is recognized that smoking and the baseline forced expiratory volume in 1 second $\left(\mathrm{FEV}_{1}\right)$ have strong effects on bronchial hyperresponsiveness. ${ }^{90,91}$ Furthermore, aging is associated with a progressive decline in lung function. ${ }^{92}$ Coupled with these findings, breathing is exaggerated 
through increased air trapping and a reduction in chest wall compliance with increased age.$^{93}$ Actually, it is reported that bronchodilators, such as long-acting beta2 agonist (LABA), have an add-on effect to inhaled corticosteroid (ICS). ${ }^{94}$

\section{Obesity}

Obesity is characterized by chronic inflammation and oxidative stress, with an increase in the mediators of innate immunity. ${ }^{95,96}$ Obesity with and without type 2 diabetes mellitus (DM) is associated with an increase in the expression of IL-4 - homologous to lymphotoxins, exhibits inducible expression, competes with HSV glycoprotein D for herpesvirus entry mediator (HVEM), which is a receptor expressed by T lymphocytes (LIGHT; homologous to lymphotoxins, exhibits inducible expression, competes with HSV glycoprotein D for HVEM, a receptor expressed by $\mathrm{T}$ lymphocytes), matrix metalloproteinase (MMP)-9, and CC chemokine receptor (CCR)-2. Following gastric bypass surgery and weight loss, the expression of these factors falls significantly. ${ }^{97}$ In addition, obesity may lead to abnormal nitric oxide (NO) metabolism, with the imbalance of 1-arginine and one of its methylated products known as asymmetric dimethyl arginine (ADMA) in obese subjects who acquire asthma after childhood. Therefore, in LOA, the plasma ratios of 1-arginine to ADMA may explain the inverse relationship between body mass index (BMI) and $\mathrm{FE}_{\mathrm{NO}}$ (reduced $\mathrm{FE}_{\mathrm{NO}}$ bioavailability in obesity). This is thought to occur because ADMA can be an endogenous inhibitor of NO synthase (NOS) isoforms. ${ }^{98}$ Actually, these lower 1-arginine/ADMA ratios are associated with reduced lung function and increased respiratory symptoms, and may have a role in the pathobiology of LOA. ${ }^{19}$ As another mechanism in the reduced value of $\mathrm{FE}_{\mathrm{NO}}$ in obesity and asthma, it is thought that since excessive airway oxidative stress in obesity reacts with $\mathrm{FE}_{\mathrm{NO}}$, the value of $\mathrm{FE}_{\mathrm{NO}}$ is apparently low in such status. ${ }^{99}$ It has been reported that, although similar cases have occurred among patients with chronic obstructive pulmonary disease (COPD), excessive nitrosative stress, such as NO, is generated in the peripheral airways. ${ }^{100}$ The same can be said of the pathophysiology of LOA, and it has been suggested that the persistent elevation of exhaled NO in the distal airway of the asthma patient can be a therapeutic target. ${ }^{101}$ However, in the actual clinical setting, ICS therapy cannot perfectly suppress the residual nitrosative stress elevation in the distal airways of asthmatics. ${ }^{101}$ In short, it is speculated that nitrosative stress in the airways may be associated with actual steroid-resistance mechanisms in some asthmatic phenotypes, such as LOA. Therefore, it can be an option to select some drugs other than ICS, such as low-dose theophylline, which might be useful to reduce nitrosative stress. ${ }^{102}$ Dietary change, such as a highly saturated meal poor in vitamin D, may contribute to the pathogenesis of asthma in obesity. ${ }^{103,104}$ High consumption of fish was reported to be protective, especially in the elderly. ${ }^{105} \mathrm{~A}$ possible mechanism for the effect of fish consumption may be derived from long-chain $\omega-3$ polyunsaturated fatty acids (PUFAs), which inhibit arachidonic acid (AA) metabolism competitively via enzymatic pathways and suppress the production of active inflammatory eicosanoid mediators from AA. ${ }^{106,107}$ A schematic view of the pathophysiology in LOA is shown in Figure 1.

\section{Diagnosis and treatment}

It is often difficult to distinguish between LOA and COPD, especially in the elderly, because both diseases have similar underlying mechanisms characterized by chronic airway inflammation and obstruction, which show analogous patterns of simple spirometric parameters. It should be taken into account that the reversibility of airway obstruction in elderly asthmatics is often reduced because of irreversible structural changes resulting from airway remodeling. ${ }^{108}$ Therefore, precise pulmonary function tests such as total lung capacity or the carbon monoxide diffusing capacity of the lungs $\left(\mathrm{DL}_{\mathrm{CO}}\right)$ can help distinguish between these diseases. ${ }^{109}$ Alternatively, it may be better to use chest imaging. Choi et al reported that, by using chest imaging biomarkers, LOA

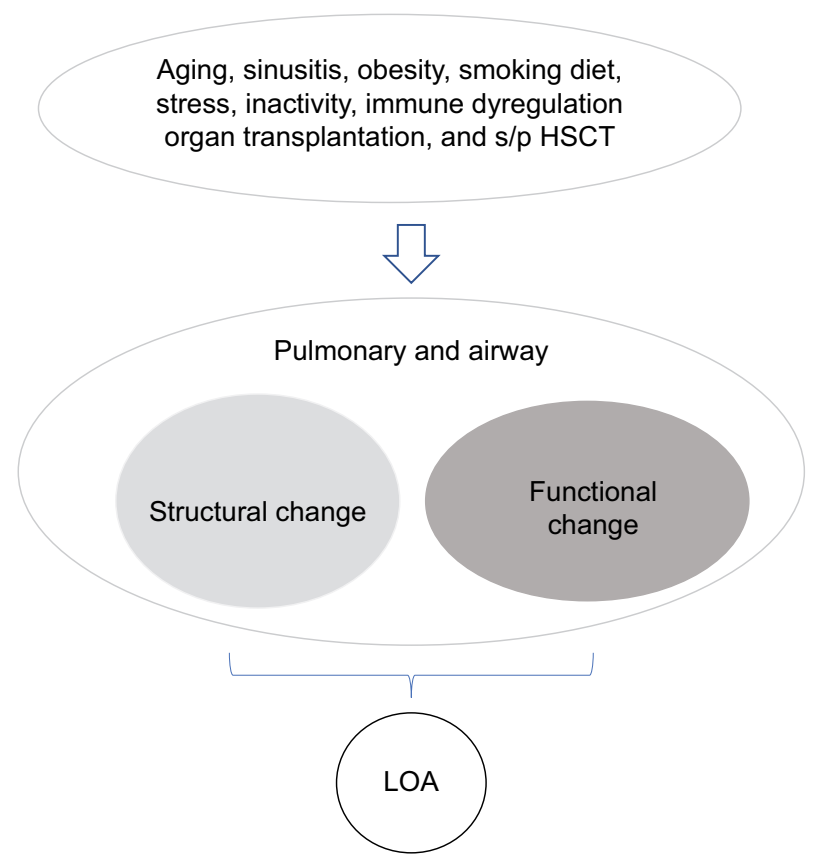

Figure I Pathophysiology of LOA. Structural or functional changes in the airway result from many factors including aging.

Abbreviations: s/p HSCT, stem/progenitor hematopoietic stem cell transplantation; LOA, late-onset asthma. 
can be identified as an imaging-based phenotype. ${ }^{110}$ It has been suggested that the imaging characteristics of LOA show airway luminal narrowing, reduced lung deformation, and increased air-trapping.

Usually, pharmacological and non-pharmacological interventions (e.g., education) are prescribed based on the phenotype. Non-pharmacological interventions, such as encouraging smoking cessation and reducing body weight, should always be pursued whenever necessary. ${ }^{111-114}$ As for pharmacological treatments, ICS is absolutely essential for Th2-LOA. ${ }^{115-117}$ Th2-type biomarkers such as blood eosinophils, $\mathrm{FE}_{\mathrm{NO}}$, and periostin are used extensively to differentiate between Th2-LOA and non-Th2-LOA. ${ }^{118,119}$ Especially, for asthma and COPD overlapping, these biomarkers are useful for predicting the responsiveness to corticosteroids. ${ }^{120-124}$ However, when corticosteroid treatment is ineffective, the clinician should consider the possibility of poor inhaler technique because elderly patients with Th2-LOA often have functional disorders. ${ }^{12,125-128}$ In such cases, assisted inhalation therapy by a caregiver might be a more useful strategy than self-administered ICS therapy. ${ }^{128}$ This strategy dovetails with the result that, even when patients with LOA are elderly, their response to treatment is similar to that in patients with EOA. ${ }^{118}$ Therefore, an upgrading strategy for poor adherence should be encouraged. ${ }^{129,130}$ If ICS treatment is truly ineffective, endotype target therapy should be taken into consideration. ${ }^{131}$ Compared with placebo, reslizumab which is a monoclonal antibody against IL-5 produces greater reductions in asthma exacerbations and larger improvements in lung function in patients with LOA versus EOA. ${ }^{132}$ Omalizumab improves all asthma outcomes independently of age, although the magnitude of the effects observed in the elderly seems to be lower than in other age groups. ${ }^{133}$ Post hoc analyses of the anti-IgE agent omalizumab indicate similar efficacy in both younger and older adults. Anti-IL-5 and anti-IL-13 therapy appear to show even more pronounced effects as targeted treatments in late-onset disease and in asthmatic patients 65 years or older, but evidence is lacking. ${ }^{45,47,134-138}$ As yet, for non-eosinophilic asthma in the elderly, there is a lack of high-level evidence for targeted therapy, but macrolides may offer a viable option. ${ }^{139}$

In Figure 2, we show the time courses of LOA with or without intervention.

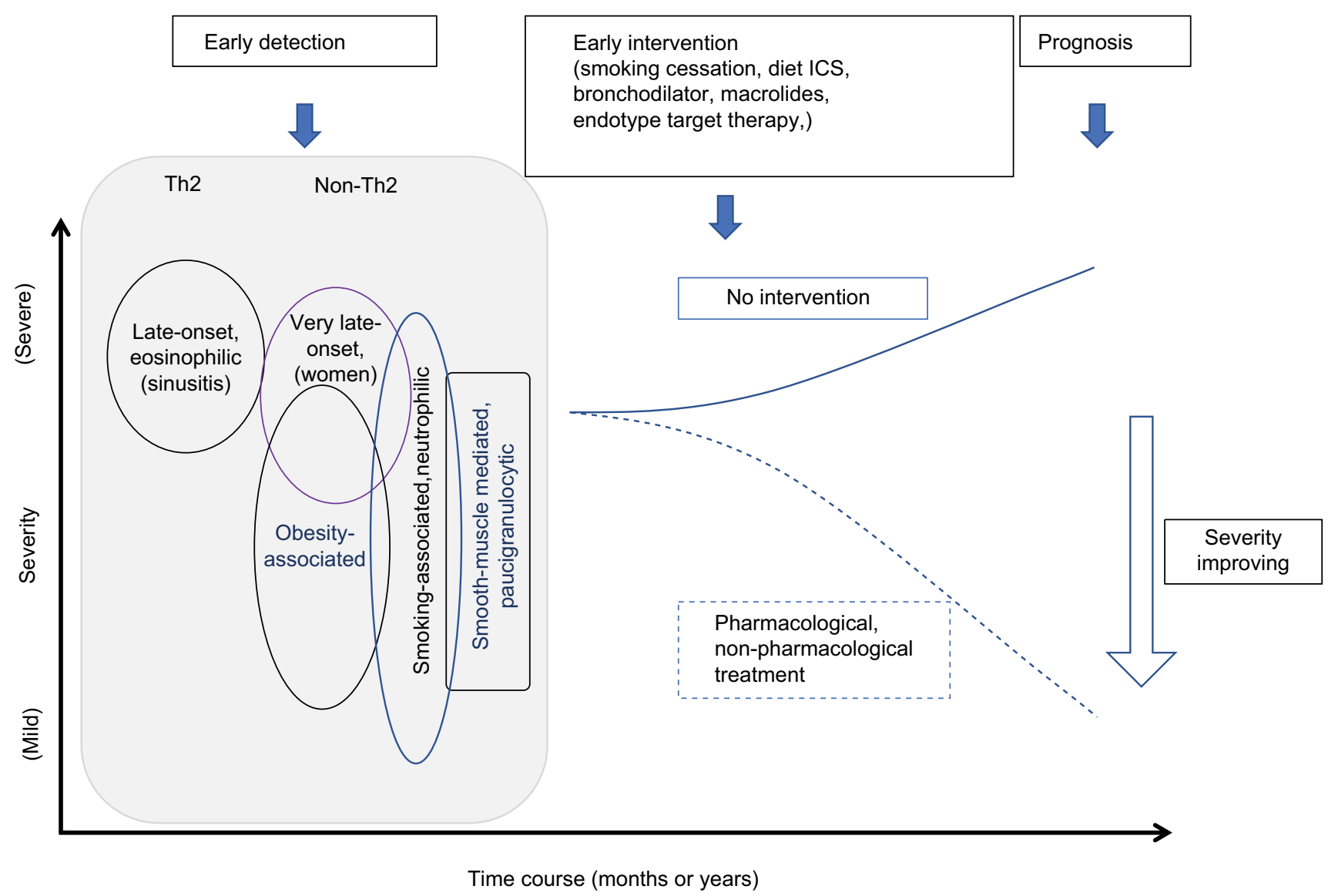

Figure 2 Time-course of LOA. The prognosis of LOA can be improved by early detection and precise intervention. Dotted and solid lines mean the time course of asthma severity by each intervention. Early intervention, such as pharmacological or non-pharmacological treatment, improve severity of asthma.

Abbreviations: Th2, T helper 2; ICS, inhaled corticosteroid; LOA, late-onset asthma. 


\section{Conclusion}

Today, advances in the understanding of the phenotypes and endotypes of asthma syndrome have helped us in managing these diverse subtypes of the disease. Because the community continues to age, LOA is beginning to play a larger role in asthma. As LOA shows different phenotypes with heterogenous backgrounds, appropriate individual management through estimating precisely the pathophysiology is required.

\section{Disclosure}

The authors report no conflicts of interest in this work.

\section{References}

1. Song WJ, Kim SH, Lim S, et al. Association between obesity and asthma in the elderly population: potential roles of abdominal subcutaneous adiposity and sarcopenia. Ann Allergy Asthma Immunol. 2012;109(4):243-248.

2. Kim YK, Kim SH, Tak YJ, et al. High prevalence of current asthma and active smoking effect among the elderly. Clin Exp Allergy. 2002;32(12):1706-1712.

3. Amelink M, de Groot JC, de Nijs SB, et al. Severe adult-onset asthma: a distinct phenotype. J Allergy Clin Immunol. 2013;132(2):336-341.

4. Lv N, Xiao L, Camargo CA Jr, et al. Abdominal and general adiposity and level of asthma control in adults with uncontrolled asthma. Ann Am Thorac Soc. 2014;11(8):1218-1224.

5. Herscher ML, Wisnivesky JP, Busse PJ, et al. Characteristics and outcomes of older adults with long-standing versus late-onset asthma. J Asthma. 2017;54(3):223-229.

6. Enright PL, McClelland RL, Newman AB, Gottlieb DJ, Lebowitz MD. Underdiagnosis and undertreatment of asthma in the elderly. Cardiovascular Health Study Research Group. Chest. 1999;116(3):603-613.

7. Ayres JG. Late onset asthma. BMJ. 1990;300(6740):1602-1603.

8. Bauer BA, Reed CE, Yunginger JW, Wollan PC, Silverstein MD. Incidence and outcomes of asthma in the elderly. A population-based study in Rochester, Minnesota. Chest. 1997;111(2):303-310.

9. Hopp RJ, Bewtra A, Nair NM, Townley RG. The effect of age on methacholine response. J Allergy Clin Immunol. 1985;76(4):609-613.

10. Miranda C, Busacker A, Balzar S, Trudeau J, Wenzel SE. Distinguishing severe asthma phenotypes: role of age at onset and eosinophilic inflammation. J Allergy Clin Immunol. 2004;113(1):101-108.

11. Sorino C, Battaglia S, Scichilone N, et al. Diagnosis of airway obstruction in the elderly: contribution of the SARA study. Int J Chron Obstruct Pulmon Dis. 2012;7:389-395.

12. Vaz Fragoso CA, Gill TM. Respiratory impairment and the aging lung: a novel paradigm for assessing pulmonary function. $J$ Gerontol A Biol Sci Med Sci. 2012;67(3):264-275.

13. Porsbjerg C, Lange P, Ulrik CS. Lung function impairment increases with age of diagnosis in adult onset asthma. Respir Med. 2015;109(7):821-827.

14. Tommola M, Ilmarinen P, Tuomisto LE, et al. The effect of smoking on lung function: a clinical study of adult-onset asthma. Eur Respir J. 2016;48(5):1298-1306.

15. Park HW, Song WJ, Kim SH, et al. Classification and implementation of asthma phenotypes in elderly patients. Ann Allergy Asthma Immunol. 2015;114(1):18-22.

16. Williams AS, Mathews JA, Kasahara DI, et al. Augmented pulmonary responses to acute ozone exposure in obese mice: roles of TNFR2 and IL-13. Environ Health Perspect. 2013;121(5):551-557.

17. Mahadev S, Salome CM, Berend N, King GG. The effect of low lung volume on airway function in obesity. Respir Physiol Neurobiol. 2013;188(2):192-199.
18. Lugogo NL, Hollingsworth JW, Howell DL, et al. Alveolar macrophages from overweight/obese subjects with asthma demonstrate a proinflammatory phenotype. Am J Respir Crit Care Med. 2012;186(5):404-411.

19. Holguin F, Comhair SA, Hazen SL, et al. An association between L-arginine/asymmetric dimethyl arginine balance, obesity, and the age of asthma onset phenotype. Am J Respir Crit Care Med. 2013;187(2):153-159.

20. Busk M, Busk N, Puntenney P, et al. Use of continuous positive airway pressure reduces airway reactivity in adults with asthma. Eur Respir J. 2013;41(2):317-322.

21. Al-Alwan A, Bates JH, Chapman DG, et al. The nonallergic asthma of obesity. A matter of distal lung compliance. Am J Respir Crit Care Med. 2014;189(12):1494-1502.

22. Scott HA, Gibson PG, Garg ML, Wood LG. Airway inflammation is augmented by obesity and fatty acids in asthma. Eur Respir J. 2011;38(3):594-602.

23. Sideleva O, Suratt BT, Black KE, et al. Obesity and asthma: an inflammatory disease of adipose tissue not the airway. Am J Respir Crit Care Med. 2012;186(7):598-605.

24. Peters MC, McGrath KW, Hawkins GA, et al; National Heart, Lung, and Blood Institute Severe Asthma Research Program. Plasma interleukin-6 concentrations, metabolic dysfunction, and asthma severity: a cross-sectional analysis of two cohorts. Lancet Respir Med. 2016;4(7):574-584.

25. Dixon AE, Poynter ME. Mechanisms of asthma in obesity. Pleiotropic aspects of obesity produce distinct asthma phenotypes. Am J Respir Cell Mol Biol. 2016;54(5):601-608.

26. Bennett WD, Ivins S, Alexis NE, et al. Effect of obesity on acute ozoneinduced changes in airway function, reactivity, and inflammation in adult females. PLoS One. 2016;11(8):e0160030.

27. Leynaert B, Sunyer J, Garcia-Esteban R, et al. Gender differences in prevalence, diagnosis and incidence of allergic and non-allergic asthma: a population-based cohort. Thorax. 2012;67(7):625-631.

28. de Nijs SB, Venekamp LN, Bel EH. Adult-onset asthma: is it really different? Eur Respir Rev. 2013;22(127):44-52.

29. Ilmarinen P, Tuomisto LE, Niemelä O, et al. Comorbidities and elevated IL-6 associate with negative outcome in adult-onset asthma. Eur Respir J. 2016;48(4):1052-1062.

30. Mayor S. Adult onset asthma may increase risk of heart disease and stroke. BMJ. 2016;354:i4685.

31. Tattersall MC, Barnet JH, Korcarz CE, Hagen EW, Peppard PE, Stein JH. Late-onset asthma predicts cardiovascular disease events: the Wisconsin sleep cohort. J Am Heart Assoc. 2016;5(9). pii: e003448.

32. Eng A, Mannetje A', Pearce N, Douwes J. Work-related stress and asthma: results from a workforce survey in New Zealand. J Asthma. 2011;48(8):783-789.

33. Labor M, Labor S, Jurić I, Fijačko V, Grle SP, Plavec D. Mood disorders in adult asthma phenotypes. J Asthma. 2017:1-9.

34. Wenzel SE. Asthma phenotypes: the evolution from clinical to molecular approaches. Nat Med. 2012;18(5):716-725.

35. Moore WC. The natural history of asthma phenotypes identified by cluster analysis. Looking for chutes and ladders. Am J Respir Crit Care Med. 2013;188(5):521-522.

36. Moore WC, Meyers DA, Wenzel SE, et al; National Heart, Lung, and Blood Institute's Severe Asthma Research Program. Identification of asthma phenotypes using cluster analysis in the Severe Asthma Research Program. Am J Respir Crit Care Med. 2010;181(4):315-323.

37. Baptist AP, Ross JA, Clark NM. Older adults with asthma: does age of asthma onset make a difference? J Asthma. 2013;50(8): $836-841$

38. Wu W, Bleecker E, Moore W, et al. Unsupervised phenotyping of Severe Asthma Research Program participants using expanded lung data. J Allergy Clin Immunol. 2014;133(5):1280-1288.

39. McDonald VM, Gibson PG. Exacerbations of severe asthma. Clin Exp Allergy. 2012;42(5):670-677. 
40. Ilmarinen P, Tuomisto LE, Niemelä O, Tommola M, Haanpää J, Kankaanranta H. Cluster analysis on longitudinal data of patients with adult-onset asthma. J Allergy Clin Immunol Pract. 2017;5(4):967-978. e3.

41. Ayres JG, Miles JF, Barnes PJ. Brittle asthma. Thorax. 1998;53(4): 315-321.

42. Hayata A, Matsunaga K, Hirano T, et al. Stratifying a risk for an increased variation of airway caliber among the clinically stable asthma. Allergol Int. 2013;62(3):343-349.

43. Frey U, Brodbeck T, Majumdar A, et al. Risk of severe asthma episodes predicted from fluctuation analysis of airway function. Nature. 2005;438(7068):667-670.

44. Kaminsky DA, Wang LL, Bates JH, et al. Fluctuation analysis of peak expiratory flow and its association with treatment failure in asthma. Am J Respir Crit Care Med. 2017;195(8):993-999.

45. de Groot JC, Storm H, Amelink M, et al. Clinical profile of patients with adult-onset eosinophilic asthma. ERJ Open Res. 2016;2(2). pii: 00100-2015. eCollection 2016.

46. de Groot JC, Amelink M, de Nijs SB, et al. Risk factors for frequent severe exacerbations in late-onset eosinophilic asthma. Am J Respir Crit Care Med. 2015;192(7):899-902.

47. Pavord ID, Korn S, Howarth P, et al. Mepolizumab for severe eosinophilic asthma (DREAM): a multicentre, double-blind, placebocontrolled trial. Lancet. 2012;380(9842):651-659.

48. Mjösberg JM, Trifari S, Crellin NK, et al. Human IL-25- and IL33-responsive type 2 innate lymphoid cells are defined by expression of CRTH2 and CD161. Nat Immunol. 2011;12(11):1055-1062.

49. Mjöosberg J, Bernink J, Golebski K, et al. The transcription factor GATA3 is essential for the function of human type 2 innate lymphoid cells. Immunity. 2012;37(4):649-659.

50. Miljkovic D, Bassiouni A, Cooksley C, et al. Association between group 2 innate lymphoid cells enrichment, nasal polyps and allergy in chronic rhinosinusitis. Allergy. 2014;69(9):1154-1161.

51. Olin AC, Rosengren A, Thelle DS, Lissner L, Bake B, Torén K. Height, age, and atopy are associated with fraction of exhaled nitric oxide in a large adult general population sample. Chest. 2006;130(5):1319-1325.

52. Mathur SK. Allergy and asthma in the elderly. Semin Respir Crit Care Med. 2010;31(5):587-595.

53. Hong JY, Bentley JK, Chung Y, et al. Neonatal rhinovirus induces mucous metaplasia and airways hyperresponsiveness through IL-25 and type 2 innate lymphoid cells. J Allergy Clin Immunol. 2014;134(2):429-439.

54. Shin HW, Kim DK, Park MH, et al. IL-25 as a novel therapeutic target in nasal polyps of patients with chronic rhinosinusitis. J Allergy Clin Immunol. 2015;135(6):1476-1485. e7.

55. Dhariwal J, Cameron A, Trujillo-Torralbo MB, et al; MRC-GSK Strategic Alliance Consortium. Mucosal type 2 innate lymphoid cells are a key component of the allergic response to aeroallergens. Am J Respir Crit Care Med. 2017;195(12):1586-1596.

56. Walker JA, Barlow JL, McKenzie AN. Innate lymphoid cells--how did we miss them? Nat Rev Immunol. 2013;13(2):75-87.

57. Wu TJ, Wu CF, Chen BY, Lee YL, Guo YL. Age of asthma onset and vulnerability to ambient air pollution: an observational populationbased study of adults from Southern Taiwan. BMC Pulm Med 2016;16(1):54.

58. Bachert C, van Steen K, Zhang N, et al. Specific IgE against Staphylococcus aureus enterotoxins: an independent risk factor for asthma. J Allergy Clin Immunol. 2012;130(2):376-381. e8.

59. Song WJ, Sintobin I, Sohn KH, et al. Staphylococcal enterotoxin IgE sensitization in late-onset severe eosinophilic asthma in the elderly. Clin Exp Allergy. 2016;46(3):411-421.

60. Schmidt F, Meyer T, Sundaramoorthy N, et al. Characterization of human and Staphylococcus aureus proteins in respiratory mucosa by in vivo- and immunoproteomics. J Proteomics. 2017;155:31-39.

61. Kowalski ML, Cieślak M, Pérez-Novo CA, Makowska JS, Bachert C. Clinical and immunological determinants of severe/refractory asthma (SRA): association with Staphylococcal superantigen-specific IgE antibodies. Allergy. 2011;66(1):32-38.
62. Huvenne W, Callebaut I, Plantinga M, et al. Staphylococcus aureus enterotoxin B facilitates allergic sensitization in experimental asthma. Clin Exp Allergy. 2010;40(7):1079-1090.

63. Bachert C, Zhang N, Holtappels G, et al. Presence of IL-5 protein and IgE antibodies to staphylococcal enterotoxins in nasal polyps is associated with comorbid asthma. J Allergy Clin Immunol. 2010;126(5):962-968, 968. e1-e6.

64. Kotzin BL, Leung DY, Kappler J, Marrack P. Superantigens and their potential role in human disease. Adv Immunol. 1993;54:99-166.

65. Patou J, Gevaert P, Van Zele T, Holtappels G, van Cauwenberge P, Bachert C. Staphylococcus aureus enterotoxin B, protein A, and lipoteichoic acid stimulations in nasal polyps. JAllergy Clin Immunol. 2008;121(1):110-115.

66. Matsumoto H, Kanemitsu Y, Nagasaki T, et al. Staphylococcus aureus enterotoxin sensitization involvement and its association with the CysLTR1 variant in different asthma phenotypes. Ann Allergy Asthma Immunol. 2017;118(2):197-203.

67. Al-Alawi M, Hassan T, Chotirmall SH. Advances in the diagnosis and management of asthma in older adults. $\mathrm{Am} \mathrm{J} \mathrm{Med.}$ 2014;127(5):370-378.

68. Johnson SA, Rozzo SJ, Cambier JC. Aging-dependent exclusion of antigen-inexperienced cells from the peripheral B cell repertoire. $J$ Immunol. 2002;168(10):5014-5023.

69. van Duin D, Mohanty S, Thomas V, et al. Age-associated defect in human TLR-1/2 function. J Immunol. 2007;178(2):970-975.

70. Vadasz Z, Haj T, Kessel A, Toubi E. Age-related autoimmunity. BMC Med. 2013;11:94.

71. Linton PJ, Dorshkind K. Age-related changes in lymphocyte development and function. Nat Immunol. 2004;5(2):133-139.

72. Haynes L, Swain SL. Why aging T cells fail: implications for vaccination. Immunity. 2006;24(6):663-666.

73. Ponnappan S, Ponnappan U. Aging and immune function: molecular mechanisms to interventions. Antioxid Redox Signal. 2011;14(8):1551-1585.

74. Candore G, Di Lorenzo G, Mansueto P, et al. Prevalence of organspecific and non organ-specific autoantibodies in healthy centenarians. Mech Ageing Dev. 1997;94(1-3):183-190.

75. Meyer KC. The role of immunity and inflammation in lung senescence and susceptibility to infection in the elderly. Semin Respir Crit Care Med. 2010;31(5):561-574.

76. King MJ, Bukantz SC, Phillips S, Mohapatra SS, Tamulis T, Lockey RF. Serum total IgE and specific IgE to Dermatophagoides pteronyssinus, but not eosinophil cationic protein, are more likely to be elevated in elderly asthmatic patients. Allergy Asthma Proc. 2004;25(5):321-325.

77. Lau MY, Dharmage SC, Burgess JA, et al. The interaction between farming/rural environment and TLR2, TLR4, TLR6 and CD14 genetic polymorphisms in relation to early- and late-onset asthma. Sci Rep. 2017;7:43681.

78. Moffatt MF, Gut IG, Demenais F, et al; GABRIEL Consortium. A largescale, consortium-based genomewide association study of asthma. $N$ Engl J Med. 2010;363(13):1211-1221.

79. Hizawa N, Yamaguchi E, Konno S, Tanino Y, Jinushi E, Nishimura M. A functional polymorphism in the RANTES gene promoter is associated with the development of late-onset asthma. Am J Respir Crit Care Med. 2002;166(5):686-690.

80. Dietz K, de Los Reyes Jiménez M, Gollwitzer ES, et al. Age dictates a steroid-resistant cascade of Wnt5a, transglutaminase 2, and leukotrienes in inflamed airways. J Allergy Clin Immunol. 2017;139(4): 1343-1354. e6.

81. Demarche S, Schleich F, Henket M, Paulus V, Van Hees T, Louis R. Detailed analysis of sputum and systemic inflammation in asthma phenotypes: are paucigranulocytic asthmatics really non-inflammatory? BMC Pulm Med. 2016;16:46.

82. Panettieri RA Jr. Neutrophilic and Pauci-immune phenotypes in severe asthma. Immunol Allergy Clin North Am. 2016;36(3):569-579.

83. Cox G, Thomson NC, Rubin AS, et al; AIR Trial Study Group. Asthma control during the year after bronchial thermoplasty. $N$ Engl $J$ Med. 2007;356(13):1327-1337. 
84. Pavord ID, Cox G, Thomson NC, et al; RISA Trial Study Group. Safety and efficacy of bronchial thermoplasty in symptomatic, severe asthma. Am J Respir Crit Care Med. 2007;176(12):1185-1191.

85. Castro M, Rubin AS, Laviolette M, et al; AIR2 Trial Study Group. Effectiveness and safety of bronchial thermoplasty in the treatment of severe asthma: a multicenter, randomized, double-blind, sham-controlled clinical trial. Am J Respir Crit Care Med. 2010;181(2):116-124.

86. Pretolani M, Bergqvist A, Thabut G, et al. Effectiveness of bronchial thermoplasty in patients with severe refractory asthma: clinical and histopathologic correlations. J Allergy Clin Immunol. 2017;139(4): 1176-1185.

87. Abreu SC, Antunes MA, Xisto DG, et al. Bone marrow, adipose, and lung tissue-derived murine mesenchymal stromal cells release different mediators and differentially affect airway and lung parenchyma in experimental asthma. Stem Cells Transl Med. 2017;6(6):1557-1567.

88. Bergeron A, Godet C, Chevret S, et al. Bronchiolitis obliterans syndrome after allogeneic hematopoietic SCT: phenotypes and prognosis. Bone Marrow Transplant. 2013;48(6):819-824.

89. Rijcken B, Schouten JP, Mensinga TT, Weiss ST, De Vries K, Van der Lende R. Factors associated with bronchial responsiveness to histamine in a population sample of adults. Am Rev Respir Dis. 1993;147(6 Pt 1): 1447-1453.

90. Burney PG, Britton JR, Chinn S, et al. Descriptive epidemiology of bronchial reactivity in an adult population: results from a community study. Thorax. 1987;42(1):38-44.

91. Paoletti P, Carrozzi L, Viegi G, et al. Distribution of bronchial responsiveness in a general population: effect of sex, age, smoking, and level of pulmonary function. Am J Respir Crit Care Med. 1995;151(6): 1770-1777.

92. Matsunaga K, Ichikawa T, Oka A, et al. Changes in forced expiratory volume in 1 second over time in patients with controlled asthma at baseline. Respir Med. 2014;108(7):976-982.

93. Matsunaga K, Akamatsu K, Miyatake A, Ichinose M. Natural history and risk factors of obstructive changes over a 10-year period in severe asthma. Respir Med. 2013;107(3):355-360.

94. Inoue H, Niimi A, Matsumoto H, et al. A 12-week, randomized, parallel-group, proof-of-concept study of tulobuterol patch and salmeterol inhaler as add-on therapy in adult-onset mild-to-moderate asthma. Clin Exp Pharmacol Physiol. 2017;44(1):21-29.

95. Hotamisligil GS, Shargill NS, Spiegelman BM. Adipose expression of tumor necrosis factor-alpha: direct role in obesity-linked insulin resistance. Science. 1993;259(5091):87-91.

96. Ghanim H, Aljada A, Hofmeyer D, Syed T, Mohanty P, Dandona P. Circulating mononuclear cells in the obese are in a proinflammatory state. Circulation. 2004;110(12):1564-1571.

97. Dandona P, Ghanim H, Monte SV, et al. Increase in the mediators of asthma in obesity and obesity with type 2 diabetes: reduction with weight loss. Obesity (Silver Spring). 2014;22(2):356-362.

98. Tran CT, Leiper JM, Vallance P. The DDAH/ADMA/NOS pathway. Atheroscler Suppl. 2003;4(4):33-40.

99. Holguin F. Arginine and nitric oxide pathways in obesity-associated asthma. J Allergy (Cairo). 2013;2013:714595.

100. Hirano T, Matsunaga K, Sugiura H, et al. Relationship between alveolar nitric oxide concentration in exhaled air and small airway function in COPD. J Breath Res. 2013;7(4):046002.

101. Hirano T, Matsunaga K, Sugiura H, et al. Persistent elevation of exhaled nitric oxide and modification of corticosteroid therapy in asthma. Respir Investig. 2013;51(2):84-91.

102. Hirano T, Yamagata T, Gohda M, et al. Inhibition of reactive nitrogen species production in COPD airways: comparison of inhaled corticosteroid and oral theophylline. Thorax. 2006;61(9):761-766

103. Wood LG, Garg ML, Gibson PG. A high-fat challenge increases airway inflammation and impairs bronchodilator recovery in asthma. JAllergy Clin Immunol. 2011;127(5):1133-1140.

104. Paul G, Brehm JM, Alcorn JF, Holguín F, Aujla SJ, Celedón JC. Vitamin D and asthma. Am J Respir Crit Care Med. 2012;185(2):124-132.
105. Uddenfeldt M, Janson C, Lampa E, et al. High BMI is related to higher incidence of asthma, while a fish and fruit diet is related to a lower- Results from a long-term follow-up study of three age groups in Sweden. Respir Med. 2010;104(7):972-980.

106. Davis BC, Kris-Etherton PM. Achieving optimal essential fatty acid status in vegetarians: current knowledge and practical implications. Am J Clin Nutr. 2003;78(3 Suppl):640S-646S.

107. Chung H, Nettleton JA, Lemaitre RN, et al. Frequency and type of seafood consumed influence plasma (n-3) fatty acid concentrations. J Nutr. 2008;138(12):2422-2427.

108. Bousquet J, Jeffery PK, Busse WW, Johnson M, Vignola AM. Asthma. From bronchoconstriction to airways inflammation and remodeling. Am J Respir Crit Care Med. 2000;161(5):1720-1745.

109. Sin BA, Akkoca O, Saryal S, Oner F, Misirligil Z. Differences between asthma and COPD in the elderly. J Investig Allergol Clin Immunol. 2006;16(1):44-50.

110. Choi S, Hoffman EA, Wenzel SE, et al; National Heart, Lung and Blood Institute's Severe Asthma Research Program. Quantitative computed tomographic imaging-based clustering differentiates asthmatic subgroups with distinctive clinical phenotypes. JAllergy Clin Immunol. 2017; 140(3):690-700. e8.

111. Eisner MD, Yelin EH, Katz PP, Shiboski SC, Henke J, Blanc PD. Predictors of cigarette smoking and smoking cessation among adults with asthma. Am J Public Health. 2000;90(8):1307-1311.

112. Gibson PG, McDonald VM, Marks GB. Asthma in older adults. Lancet. 2010;376(9743):803-813.

113. Park HW, Kim TW, Song WJ, et al. Prediction of asthma exacerbations in elderly adults: results of a 1-year prospective study. J Am Geriatr Soc. 2013;61(9):1631-1632.

114. Westerhof GA, Vollema EM, Weersink EJ, Reinartz SM, de Nijs SB, Bel EH. Predictors for the development of progressive severity in new-onset adult asthma. J Allergy Clin Immunol. 2014;134(5):1051-1056. e2.

115. Sin DD, Tu JV. Inhaled corticosteroid therapy reduces the risk of rehospitalization and all-cause mortality in elderly asthmatics. Eur Respir J. 2001;17(3):380-385.

116. Slavin RG, Haselkorn T, Lee JH, Zheng B, Deniz Y, Wenzel SE; TENOR Study Group. Asthma in older adults: observations from the epidemiology and natural history of asthma: outcomes and treatment regimens (TENOR) study. Ann Allergy Asthma Immunol. 2006;96(3):406-414.

117. Haughney J, Aubier M, Jørgensen L, et al. Comparing asthma treatment in elderly versus younger patients. Respir Med. 2011;105(6):838-845.

118. Matsunaga K, Akamatsu K, Hirano T, Ichinose M. Response to treatment in individuals with late-onset asthma. J Am Geriatr Soc. 2012;60(8):1587-1588.

119. Matsusaka M, Kabata H, Fukunaga K, et al. Phenotype of asthma related with high serum periostin levels. Allergol Int. 2015;64(2):175-180.

120. Akamatsu K, Matsunaga K, Sugiura H, et al. Improvement of airflow limitation by fluticasone propionate/salmeterol in chronic obstructive pulmonary disease: what is the specific marker? Front Pharmacol. 2011;2:36

121. Kunisaki KM, Rice KL, Janoff EN, Rector TS, Niewoehner DE. Exhaled nitric oxide, systemic inflammation, and the spirometric response to inhaled fluticasone propionate in severe chronic obstructive pulmonary disease: a prospective study. Ther Adv Respir Dis. 2008; 2(2):55-64.

122. Zietkowski Z, Kucharewicz I, Bodzenta-Lukaszyk A. The influence of inhaled corticosteroids on exhaled nitric oxide in stable chronic obstructive pulmonary disease. Respir Med. 2005;99(7):816-824.

123. Ferreira IM, Hazari MS, Gutierrez C, Zamel N, Chapman KR. Exhaled nitric oxide and hydrogen peroxide in patients with chronic obstructive pulmonary disease: effects of inhaled beclomethasone. Am J Respir Crit Care Med. 2001;164(6):1012-1015.

124. Kupczyk M, Haque S, Middelveld RJ, Dahlén B, Dahlén SE; BIOAIR Investigators. Phenotypic predictors of response to oral glucocorticosteroids in severe asthma. Respir Med. 2013;107(10):1521-1530. 
125. Turan O, Turan PA, Mirici A. Parameters affecting inhalation therapy adherence in elderly patients with chronic obstructive lung disease and asthma. Geriatr Gerontol Int. 2017;17(6):999-1005.

126. Wieshammer S, Dreyhaupt J. Dry powder inhalers: which factors determine the frequency of handling errors? Respiration. 2008;75(1):18-25.

127. Melani AS, Bonavia M, Cilenti V, et al; Gruppo Educazionale Associazione Italiana Pneumologi Ospedalieri. Inhaler mishandling remains common in real life and is associated with reduced disease control. Respir Med. 2011;105(6):930-938.

128. Matsunaga K, Yamagata T, Minakata Y, Ichinose M. Importance of assistance by caregivers for inhaled corticosteroid therapy in elderly patients with asthma. J Am Geriatr Soc. 2006;54(10):1626-1627.

129. Ulrik CS. Late-onset asthma: a diagnostic and management challenge. Drugs Aging. 2017;34(3):157-162.

130. Burdon J.Adult-onset asthma. Aust Fam Physician. 2015;44(8):554-557.

131. Skloot GS. Asthma phenotypes and endotypes: a personalized approach to treatment. Curr Opin Pulm Med. 2016;22(1):3-9.

132. Brusselle G, Germinaro M, Weiss S, Zangrilli J. Reslizumab in patients with inadequately controlled late-onset asthma and elevated blood eosinophils. Pulm Pharmacol Ther. 2017;43:39-45.
133. Sposato B, Scalese M, Latorre M, et al. Effects of omalizumab in severe asthmatics across ages: a real life Italian experience. Respir Med. 2016;119:141-149.

134. Rubinsztajn R, Chazan R. Monoclonal antibodies for the management of severe asthma. Adv Exp Med Biol. 2016;935:35-42.

135. Piper E, Brightling C, Niven R, et al. A phase II placebo-controlled study of tralokinumab in moderate-to-severe asthma. Eur Respir J. 2013;41(2):330-338

136. Ortega HG, Liu MC, Pavord ID, et al; MENSA Investigators. Mepolizumab treatment in patients with severe eosinophilic asthma. $N$ Engl J Med. 2014;371(13):1198-1207.

137. Bel EH, Wenzel SE, Thompson PJ, et al; SIRIUS Investigators. Oral glucocorticoid-sparing effect of mepolizumab in eosinophilic asthma. N Engl J Med. 2014;371(13):1189-1197.

138. Gevaert P, Van Bruaene N, Cattaert T, et al. Mepolizumab, a humanized anti-IL-5 mAb, as a treatment option for severe nasal polyposis. J Allergy Clin Immunol. 2011;128(5):989-995. e1-e8.

139. de Roos EW, In 't Veen JC, Braunstahl GJ, Lahousse L, Brusselle GG. Targeted therapy for older patients with uncontrolled severe asthma: current and future prospects. Drugs Aging. 2016;33(9):619-628.
Journal of Asthma and Allergy

\section{Publish your work in this journal}

The Journal of Asthma and Allergy is an international, peer-reviewed open access journal publishing original research, reports, editorials and commentaries on the following topics: Asthma; Pulmonary physiology; Asthma related clinical health; Clinical immunology and the immunological basis of disease; Pharmacological interventions and

\section{Dovepress}

new therapies. This journal is included in PubMed. The manuscript management system is completely online and includes a very quick and fair peer-review system, which is all easy to use. Visit http://www. dovepress.com/testimonials.php to read real quotes from published authors. 